\title{
Day Lighting as a tool of Energy Saving in Buildings for Remote Regions
}

\author{
M. Osama abed el-Raouf ${ }^{1}$, Adel. Mallawany ${ }^{2}$, Mohamed I. Mosaad \\ ${ }^{3}$ Mahmoud A. Al-Ahmar ${ }^{4}$ and Fahmy M El Bendary 5
}
1, 2 Building Physics and Environmental Research Institute, Housing and Building, National Research, ${ }^{3}$ Higher Technological Institute-Egypt on leave to YIC, KSA, 4, 5 Benha University, Shoubra faculty of engineering Cairo, Egypt

\begin{abstract}
There is no doubt that daylight plays a major role in the saving of electrical energy, especially in new buildings. This paper presents a case study of a building in the new Farafra area of Egypt with the use of daylight as a means of energy saving. Environmental factors which include solar radiation and weather conditions, building factors such as building type, windows, surrounding buildings, etc., factors for planning the rooms in the building such as partitioning, furniture arrangement, occupancy rate, etc., all of the above factors have made deleting a very dynamic element. There is no need for any building materials as the proposed site contains building materials required. The analysis of Daylighting presented in all seasons of the year in the selected site. According to simulation results in a winter day as the worst case of an office room, the artificial lighting is not needed from 9:30 AM to 3:00 PM, for a bedroom the artificial lighting is not needed from 8:30 AM to 4:15 PM, for living room the artificial lighting is not needed from 8:30 AM to 4:00 PM. For the kitchen, the artificial lighting is not needed from 8:45 AM to 4:00 PM. Results show that the monthly energy saving is about $83.1 \mathrm{kWh}$, the adaptive thermal comfort of indoor environment control is actually balanced in terms of occupancy, comfort, and energy efficiency, the window to wall ratio is taken into account during simulations and energy saving due to thermal comfort with no need for an air-conditioning system is about $1350 \mathrm{kWh}$.
\end{abstract}

Key Words: Day lighting, lighting simulation, DIALux, building model, efficient energy.

\section{INTRODUCTION}

There is no doubt that light is one of the most important elements of life, and therefore it is necessary to adapt all human activities. Providing light, whether natural or industrial, is a basic condition in any architectural vacuum, and the methods of architects vary in securing the required quantities of light in their designs [1]. Daylighting is an important issue in modern buildings and architectural sciences, which has a great impact on the visual and thermal comfort of people and energy saving in buildings and affects the internal division of spaces, the arrangements of furniture and the occupancy in the buildings [2]. Apart from the light of the sky, the interior light of the building depends on internal and external factors. Internally, the size and type of windows, dimensions, and colors of the rooms as for external factors, the reflected light of the streets and external facades can be a source of light inside the building [3]. This paper presents the using daylight as a tool in energy saving in the buildings. The site proposed is located in rural areas in Farafra oasis - Egypt, the area of the building proposed about 153m2, it consists of living room, three bedrooms, office room, kitchen, two toilets and two balconies. In this study, the area of the window in office rooms $=3 \mathrm{~m} 2$, in bedrooms $=3 \mathrm{~m} 2$, in living room $=2 \mathrm{~m} 2$ and in kitchen $=1.2 \mathrm{~m} 2$, where, according to Egyptian energy codes the window to wall ratio is selected as $30 \%$ In each space the daylight is calculated using simulation tools, then the hours of daylight at which artificial lighting not needed are calculated for each space, after this the energy saving is calculated by multiplying the number of hours of not using artificial lighting and wattage of luminaires when using artificial lighting. According to this study, the building must be thermally comfortable so that the design-builder software is used as a simulation tool in calculating the indoor temperature, then energy saving is calculated where the air conditioning not needed.

\section{DAYLIGHTING AND ENERGY EFFICIENCY}

A large amount of carbon dioxide is emitted as a result of the use of artificial lighting, which leads to global warming. Artificial lighting consumes about $40 \%$ of the annual energy consumption of the building [4], commercial buildings consume a large 
proportion of electrical energy [5]. Solar energy has important benefits includes lighting and heating. Building elements are used in storing and distributing solar energy under the concept of passive solar energy. Daylighting is one of the most strategies, architecture, engineering, it contributes to the energy saving and energy efficiency in buildings [4-5]. Literature indicated that a reduction of 223 million tonnes of co2 emissions by using Daylighting [6]. On the other hand, excessive Daylighting has a negative effect on thermal comfort to building occupants [7].

\section{BUILDING MODEL}

Any building may include information about its geometry, size, length, width, doors, windows... etc. buildings have some elements which are used as an important role in adjusting thermal comfort and energy saving. These elements are represented in size of windows, building materials and building physical properties. Firstly, CAD tools are used to build the building model, then DIALux software used to simulate the building through importing models from CAD tool. In this paper, DIALux is used to simulate the Daylighting of building proposed. DIALux has many advantages such as simplicity, data visualization and analysis outputs, 3D rendering....etc. In this paper, the site selected is based on some studies [8-10]. New Farafra Oasis-extends northeast between latitudes $27^{\circ} 03^{\prime} \mathrm{N}$ and $26^{\circ} 58^{\prime} \mathrm{E}$ to latitudes $27^{\circ} 22^{\prime} 30 \mathrm{~N}$ and $27^{\circ} 24^{\prime} \mathrm{E}$, with a maximum $\mathrm{NE}$ length of $52 \mathrm{~km}$ and a maximum width of $20 \mathrm{~km}$, attaining a total area of $932 \mathrm{~km} 2$ [10]. For Daylighting calculations the latitude and longitude are used as an input in the program. Alignment of the building is important for Daylighting calculations so that the building orientation with the geographic north, east, west, south are investigated. Fig. 1 shows the layout of the proposed building with an area of about 156 $\mathrm{m} 2$. It consists of 3-bedrooms, living room, 2 balcony, office room, 2 toilets, and kitchen. Building dimensions in details are shown in this figure.

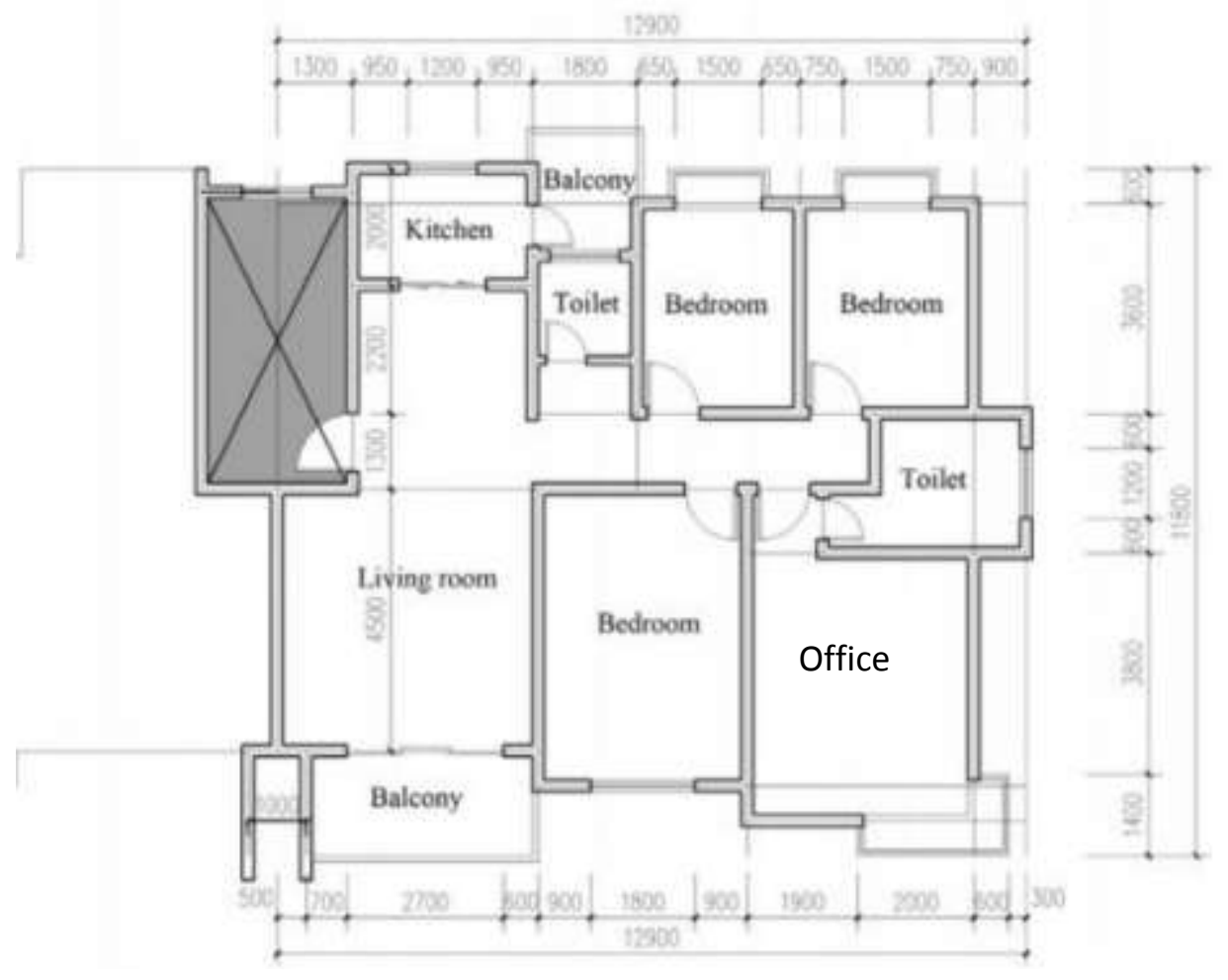

Figure 1: Layout of Building Model

\section{BUILDING MATERIALS AVAILABLE ON THE SELECTED SITE}

To find all these mineral wealth, vast areas, buried treasures in the ground or on the surface, and then find crises in resources, a severe budget deficit, high unemployment rates, and large population congestion because of the establishment of the population on $6 \%$ of the total area of Egypt, forcing them To build on agricultural land, and the implications of multiple crises for current and future generations. Because Egypt is facing a difficult trilogy, a country with most of its territory is a desert of rare water, a large population divided into a narrow space and limited economic resources. It was, therefore, important to seek scientific and realistic solutions to our current crises so that, the use of the desert in the establishment of new communities is an important issue [8]. Farafra Oasis is a natural museum where there is a white desert, which contains exquisite natural shapes and different sizes and landscapes. Farafra Oasis also has large areas of land suitable for agriculture, so the project of the age is recommended to be an oasis of Farafra a tourist site for geology and hospitalization in addition to increasing the area of green land, especially as there is 
great potential for the existence of quantities of groundwater to reclamation of many acres and planting crops Occasion. The new proposed site was chosen is new EL-Farafra Oasis to establish a new urban community. The building materials available in this site, Shale/clay soil is available there which allows agricultural and industrial development. Limestone in the oasis with shale/clay soil form local building materials. Fig. 2, shows the building materials map which is available in Egypt. The selected site contains areas with loose river, dune or beach sediment deposits [10].

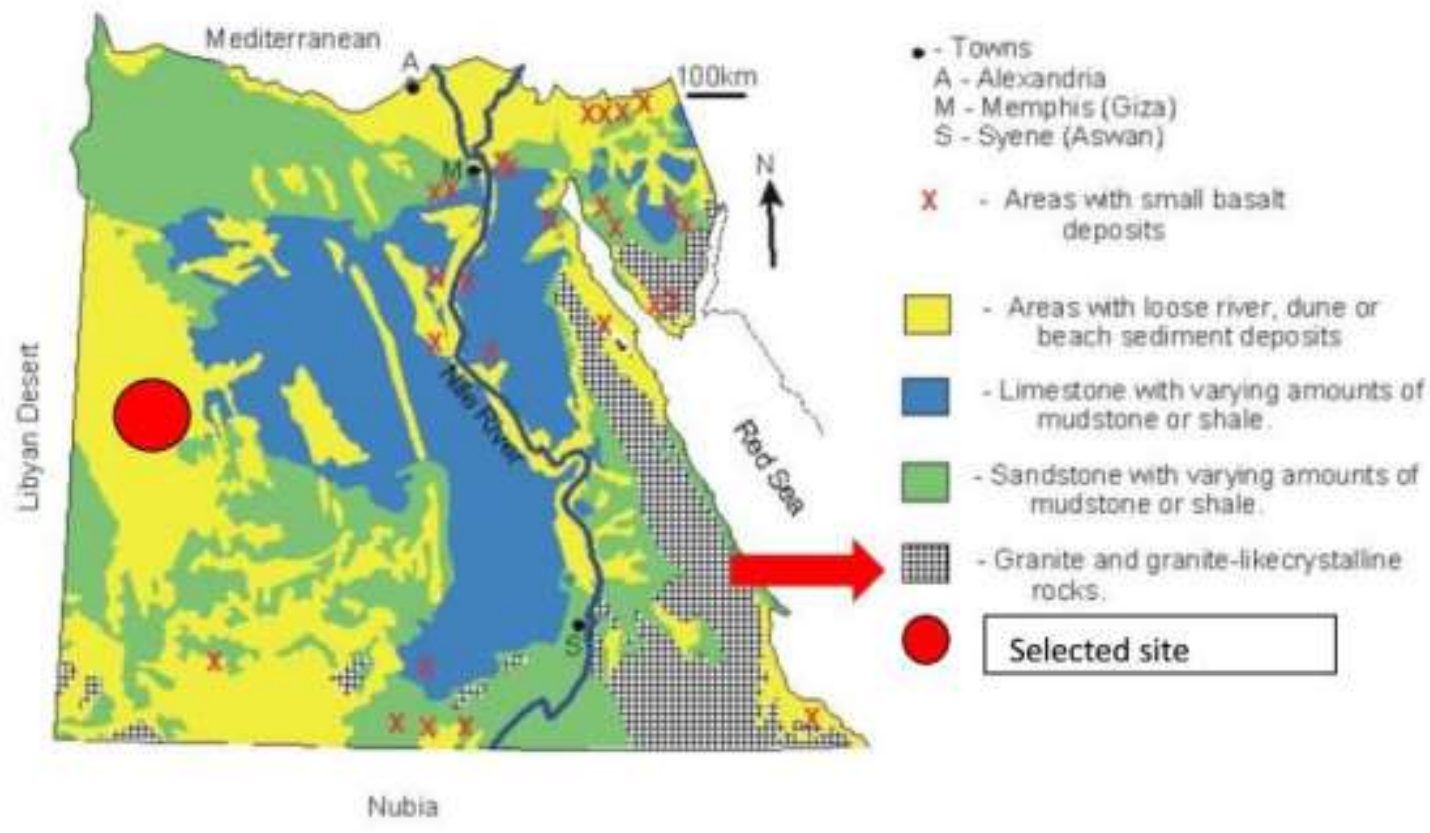

Figure 2: Simplified Lithological Map of Egypt

The opening design details of the model are shown in the table 1. The construction of the proposed building, building materials, thickness and U-value of the building envelope are shown in the table 2, which are used as inputs to model the building proposed.

\section{THERMAL COMFORT AND BUILDING ENVELOPE AS A TOOL OF ENERGY SAVING}

Thermal comfort is a necessary and urgent requirement for users of interior spaces in contemporary times. It is considered an indicator of the quality of the internal environment where it provides a healthy and productive environment [11]. In addition to achieving the thermal comfort in the buildings, it provides sustainability and energy saving. Therefore, the thermal comfort in all buildings, especially residential buildings, should be achieved as the place where most of the time is spent. Some factors affecting thermal comfort:

- Type of building envelope material

- The thickness of the building walls

- Window to wall ratio

- Glass thickness and quality

- Air temperature

- Air velocity

- Relative humidity (RH)

- Clothing, Metabolic heat and Wellbeing, and sicknesses.

Table 1. Building opening construction and its $U$-value

\begin{tabular}{|c|l|c|c|}
\hline Components & \multicolumn{1}{|c|}{ Material Layer } & $\begin{array}{c}\text { Thickness } \\
(\mathbf{m})\end{array}$ & $\begin{array}{c}\text { U-value } \\
(\mathbf{W} / \mathbf{m} 2-\mathbf{K})\end{array}$ \\
\hline Internal window & UPVC window frame+DblClr 6 mm/6 mm Air & 0.018 & 3.157 \\
\hline External window & $\begin{array}{l}\text { UPVC window frame+DblLoE (e2=0.1) Clr 6 mm/13 mm } \\
\text { Air }\end{array}$ & 0.025 & 1.772 \\
\hline External window & UPVC window frame (Polyvinylchloride) & 0.02 & 3.467 \\
\hline
\end{tabular}


M. Osama abed el-Raouf et. al., Day lighting as a tool of energy saving in buildings ....

Table 2. Building construction design and its $U$-value

\begin{tabular}{|c|l|c|c|}
\hline Components & Material Layer & $\begin{array}{c}\text { Thickness } \\
(\mathbf{m})\end{array}$ & $\begin{array}{c}\text { U-value } \\
(\mathbf{W} / \mathbf{m} 2-\mathbf{K})\end{array}$ \\
\hline \multirow{5}{*}{ External wall } & Cement/plaster/mortar-cement plaster (Outer) & 0.015 & \\
& EPS expanded polystyrene (lightweight) & 0.02 & 0.946 \\
& Hollow clay brick & 0.2 & \\
& Cement/plaster/mortar-cement plaster (inner) & 0.015 & \\
& & & 2.061 \\
\hline \multirow{2}{*}{ Internal wall } & Plaster (dense) & 0.02 & 0.2 \\
& Brick-burned & 0.02 & \\
\hline \multirow{2}{*}{ Floor } & Plaster (dense) & 0.20 & 2.23 \\
& Cast concrete & 0.005 & \\
& Ceramic floor tiles dry & 0.04 & \\
& Concrete, cast-lightweight & 0.005 & \\
& Glass fiber quilt & 0.030 & 0.743 \\
& EPS expanded polystyrene (lightweight) & 0.020 & \\
& Cement/plaster/mortar-cement plaster & 0.005 & \\
& Asphalt mastic roofing & 0.02 & \\
& Cement plaster & 0.005 & \\
\hline Flat roof & Gypsum plaster, perlite aggregate & 0.200 & 2.500 \\
& Concrete, cast-dense, reinforced & 0.042 & 2.557 \\
\hline Internal door & Solid hardwood door (normally hung) & & \\
\hline External door & Wooden flush panel hollow core door & & \\
& & & \\
\hline
\end{tabular}

\section{RESULTS}

The analysis of Daylighting presented in all seasons of the year in the selected site according to the following cases:

Case 1: Daylighting in spring, If the area of the window in office room $=3 \mathrm{~m}^{2}$, Window to wall ratio $=30 \%$ as in figure 3 . From this figure, the artificial lighting is not needed from 8:00 AM to 5:00 PM.

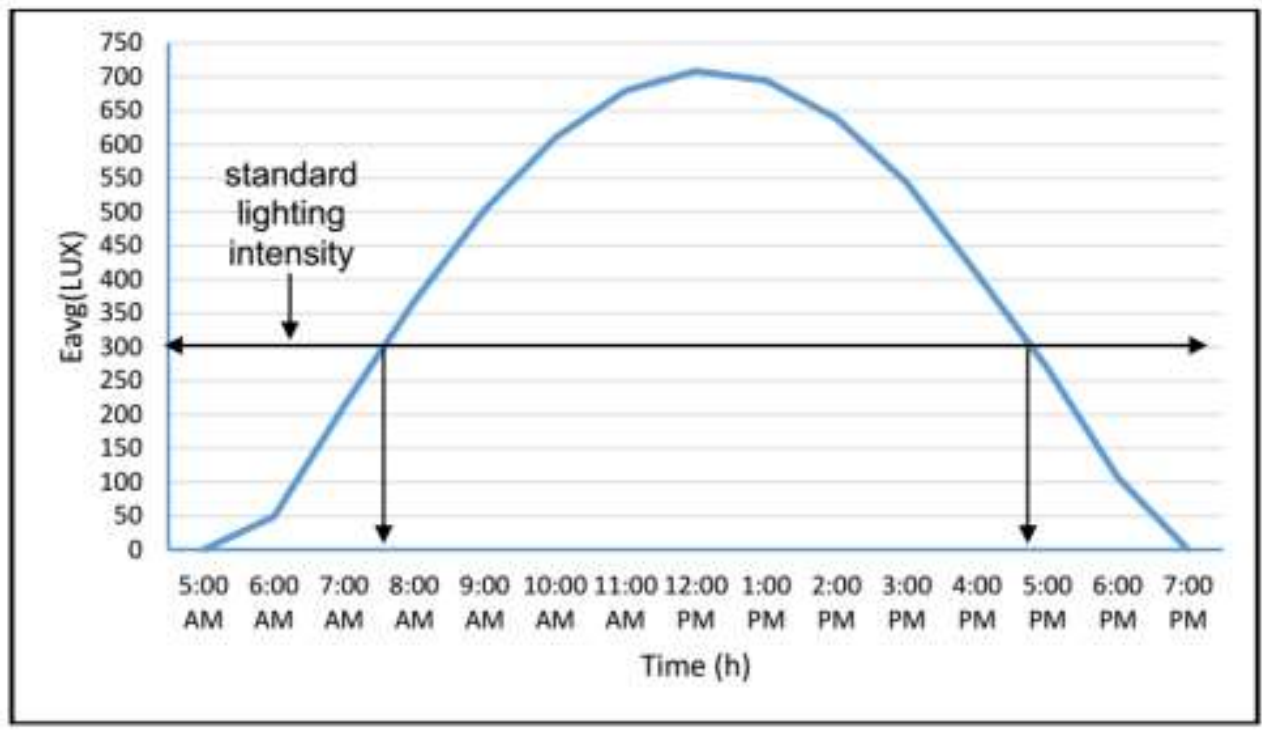

Figure 3: Daylighting in Spring Day in the Office Room 
International Journal of Advances in Scientific Research and Engineering (ijasre), Vol 4 (7), July - 2018

Case 2: Daylighting in summer, If the area of the window in office room $=3 \mathrm{~m}^{2}$, window to wall ratio $=30 \%$ as in figure 4 . From this figure, the artificial lighting is not needed from 7:45 AM to 5:15 PM.

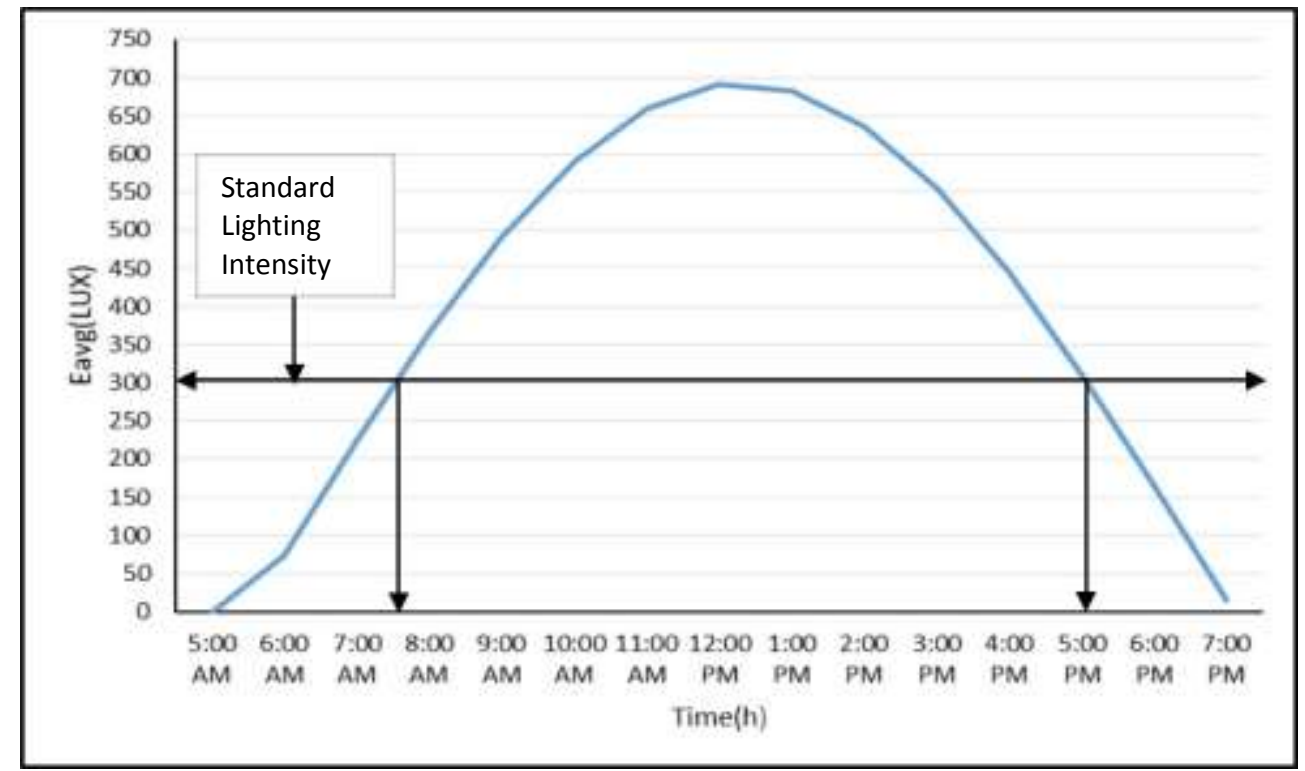

Figure 4: Daylighting on a Summer Day in the Office Room

Case 3: Daylighting in autumn, If the area of the window in office room $=3 \mathrm{~m}^{2}$, window to wall ratio $=30 \%$ as in figure 5 . From this figure, the artificial lighting is not needed from 8:30 AM to 3:45 PM.

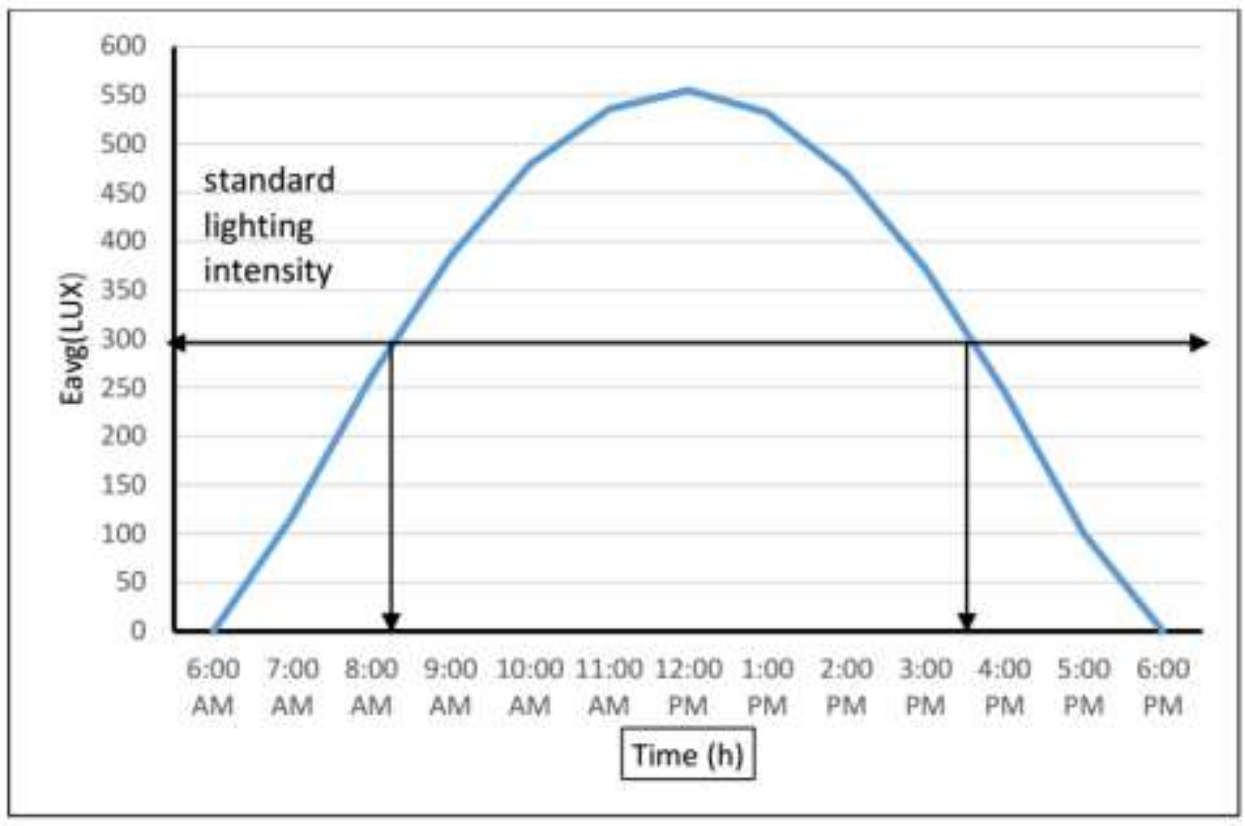

Figure 5: Daylighting in the Autumn Day in the Office Room

Case 4: Daylighting in winter, If the area of the window in office room $=3 \mathrm{~m}^{2}$, window to wall ratio $=30 \%$ as in figure 6 . From this figure, the artificial lighting is not needed from 9:30 AM to 3:00 PM. 
M. Osama abed el-Raouf et. al., Day lighting as a tool of energy saving in buildings ....

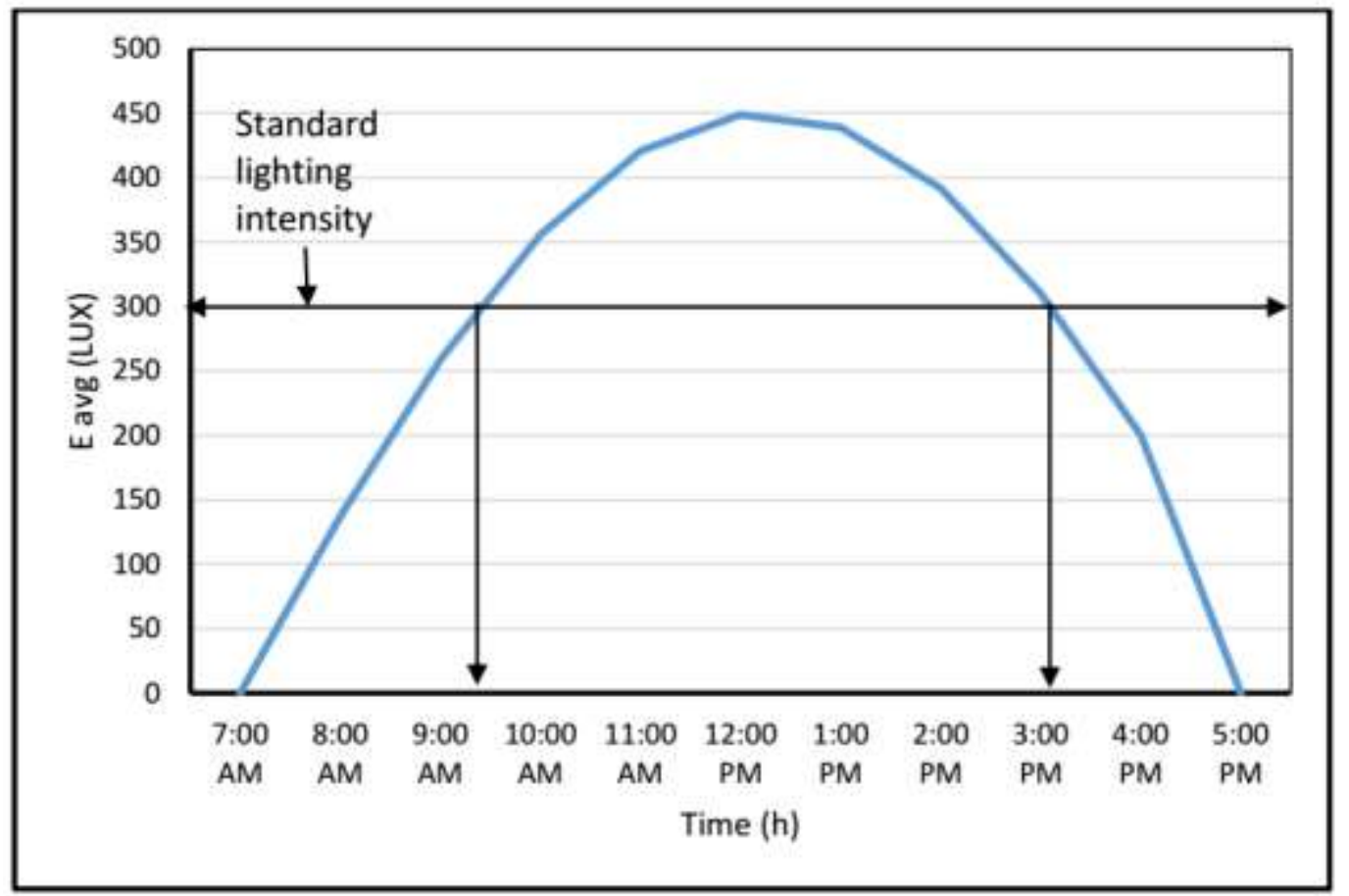

Figure 6: Daylighting in a Winter Day in the Office Room

Case 5: Daylighting in all seasons, If the area of the window in bedrooms $=3 \mathrm{~m}^{2}$, window to wall ratio $=30 \%$ as in figure 7 . From this figure, the artificial lighting is not needed from 8:30 AM to 4:15 PM on a winter day as the worst case.

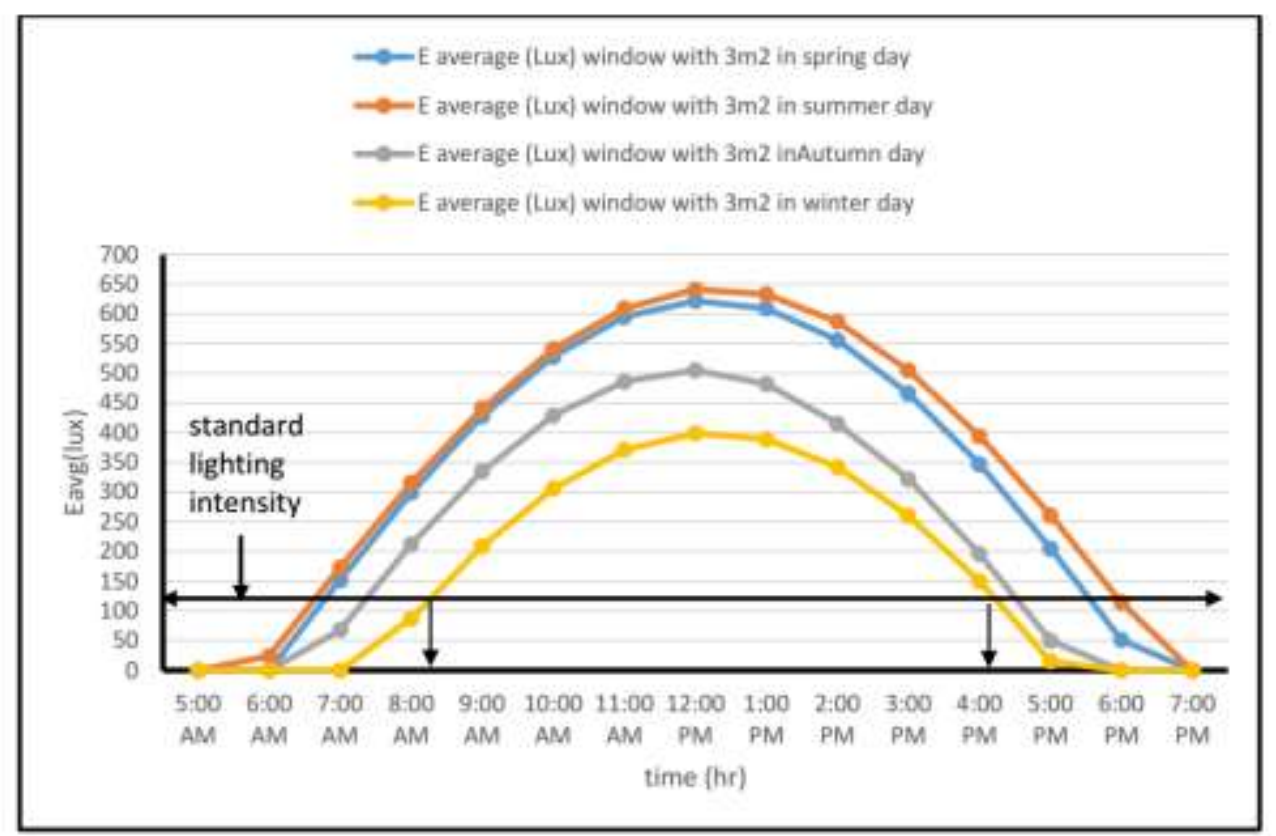

Figure 7: Daylighting in all Seasons for Bedrooms

Case 6: Daylighting in all seasons, If the area of the window in living room $=2 \mathrm{~m}^{2}$, window to wall ratio $=30 \%$ as in figure 8 . From this figure, the artificial lighting is not needed from 8:30 AM to 4:00 PM in winter day as the worst case. 


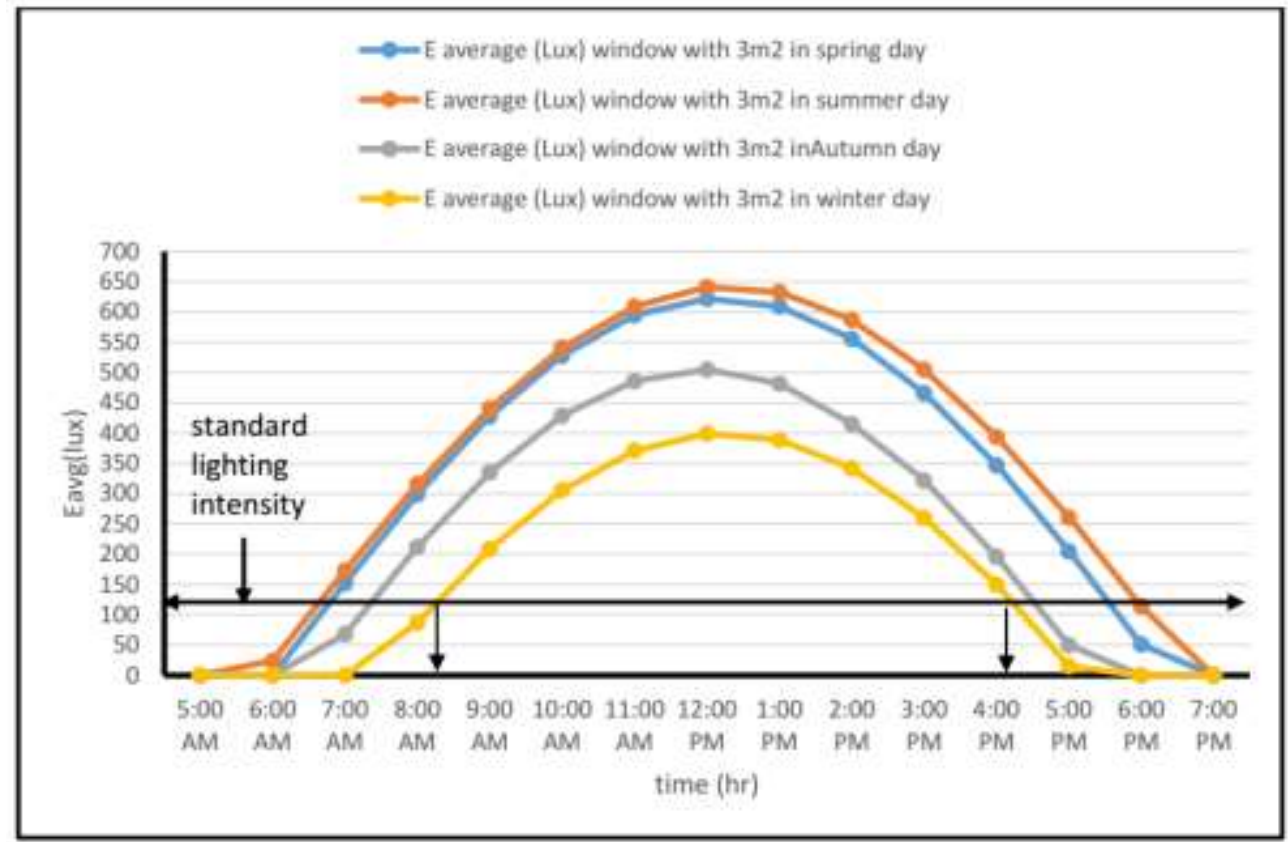

Figure 8: Daylighting in all Seasons for Living Rooms

Case 7: Daylighting in all seasons, If the area of the window in kitchen $=1.2 \mathrm{~m}^{2}$, window to wall $\quad$ ratio $=30 \%$ as in figure 9 . From this figure, the artificial lighting is not needed from 8:45 AM to 4:00 PM in winter day as the worst case.

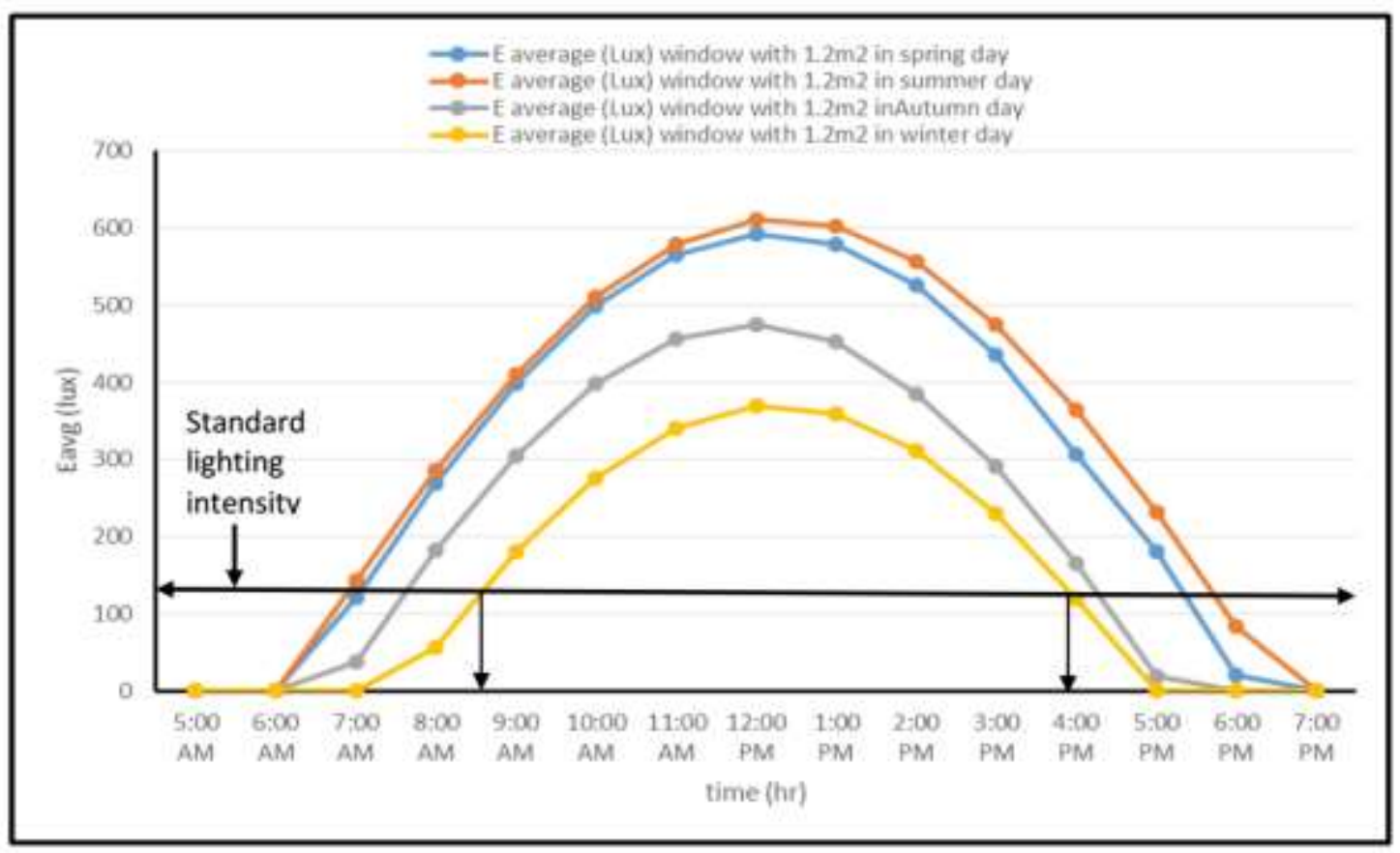

Figure 9: Daylighting in all seasons for kitchen

\section{Energy saving calculations [12]}

Luminous efficacy $\epsilon(\mathrm{lm} / \mathrm{W})$ is a measure of visible light produced by a light source.it is expressed by the following equation:

$$
\epsilon=\Phi / \mathrm{p} \quad(\mathrm{lm} / \mathrm{W})
$$

Where: $\Phi$ : is the luminous flux, $\mathrm{p}$ : is the electrical power. In the case of the artificial light, the power (p) represents the consumed power by the light source but, in the case of Daylighting, (p) represents solar radiation in the given area.

The total electrical power savings $\mathrm{P}(\mathrm{W})$ corresponding to the luminous flux for the measured luminance level on a given horizontal surface can be obtained using the following equation: 
M. Osama abed el-Raouf et. al., Day lighting as a tool of energy saving in buildings ....

$$
\mathrm{P}(\mathrm{w})=\Phi /(\epsilon * \mathrm{Bf})
$$

Where $\mathrm{BF}$ is ballast factor and

$$
\Phi=\mathrm{L}(\mathrm{lux}) * \mathrm{~A}\left(\mathrm{~m}^{2}\right)
$$

"Equation (2)" can be used to evaluate the daily, monthly, and annual power consumed in kWh for a given luminance. From fig.3 to fig.7 the results shows that for an office room in the worst case in winter day the artificial lighting is not needed for 9:30 A.M to 3:00 P.M so that energy saved about $(5.5 \mathrm{~h} *$ wattage of luminaires required when artificial lighting is used) which equal $5.5 \mathrm{~h} * 258$ $\mathrm{w}=1419 \mathrm{Wh} /$ day $=42570 \mathrm{Wh} /$ month. For bedroom at the worst case in a winter day, the artificial lighting is not needed from 8:30 AM to 4:15 PM so that energy saved about $(7.65 \mathrm{~h}$ * wattage of luminaires required when artificial lighting is used) which equal $7.65 \mathrm{~h} * 86 \mathrm{w}=685 \mathrm{Wh} /$ day $=19740 \mathrm{Wh} /$ month. For all bedrooms, the monthly energy saved about $59220 \mathrm{Wh} / \mathrm{month}$. For a living room at the worst case on a winter day, the artificial lighting is not needed from 8:30 AM to 4:00 PM so that energy saved ( $7.5 \mathrm{~h} *$ wattage of luminaires required when artificial lighting is used) which equal $7.5 \mathrm{~h} * 129 \mathrm{w}=968 \mathrm{Wh} / \mathrm{day}=29040 \mathrm{Wh} /$ month. For kitchen at the worst case in a winter day, the artificial lighting is not needed from 8:45 AM to 4:00 PM so that energy saved about ( $7.55 \mathrm{~h} *$ wattage of luminaires required when artificial lighting is used) which equal $7.55 \mathrm{~h} * 43 \mathrm{w}=325 \mathrm{Wh} / \mathrm{day}=$ $9750 \mathrm{Wh} /$ month. From simulations and calculations, the monthly energy saved is shown in the table 3.

Table 3. Monthly Energy Saved

\begin{tabular}{|l|l|}
\hline Building & Monthly energy saved \\
\hline Office room & $42570 \mathrm{Wh}$ \\
\hline Bedrooms & $19740 \mathrm{Wh}$ \\
\hline Living room & $29040 \mathrm{Wh}$ \\
\hline Kitchen & $9750 \mathrm{Wh}$ \\
\hline Sum & $83100 \mathrm{Wh}$ \\
\hline
\end{tabular}

By using ASHRAE Standard 55-2017 and PMV method, inputs to design-builder software for selected site are: air temperature = $25^{\circ} \mathrm{c}$, mean radiant temperature $=28^{\circ} \mathrm{c}$, humidity $=30 \%$, airspeed $=0.1 \mathrm{~m} / \mathrm{s}$, metabolic rate $=1.1$ met and clothing level $=0.5$ at typical summer indoor. By running simulation, results show that, the Predicted Mean Vote (PMV) $=0.2$ where the comfort zone is defined as the PMV is within the recommended limits $(-0.5<\mathrm{PMV}<+0.5)$ [13], Predicted Percentage Dissatisfied (PPD) $=6 \%$, sensation is neutral and set point value temperature $=25.7^{\circ} \mathrm{c}$, these results Complies with ASHRAE Standard 55-2017[14]. Figure 10 , shows the relation between dray bulb temperature and humidity ratio.

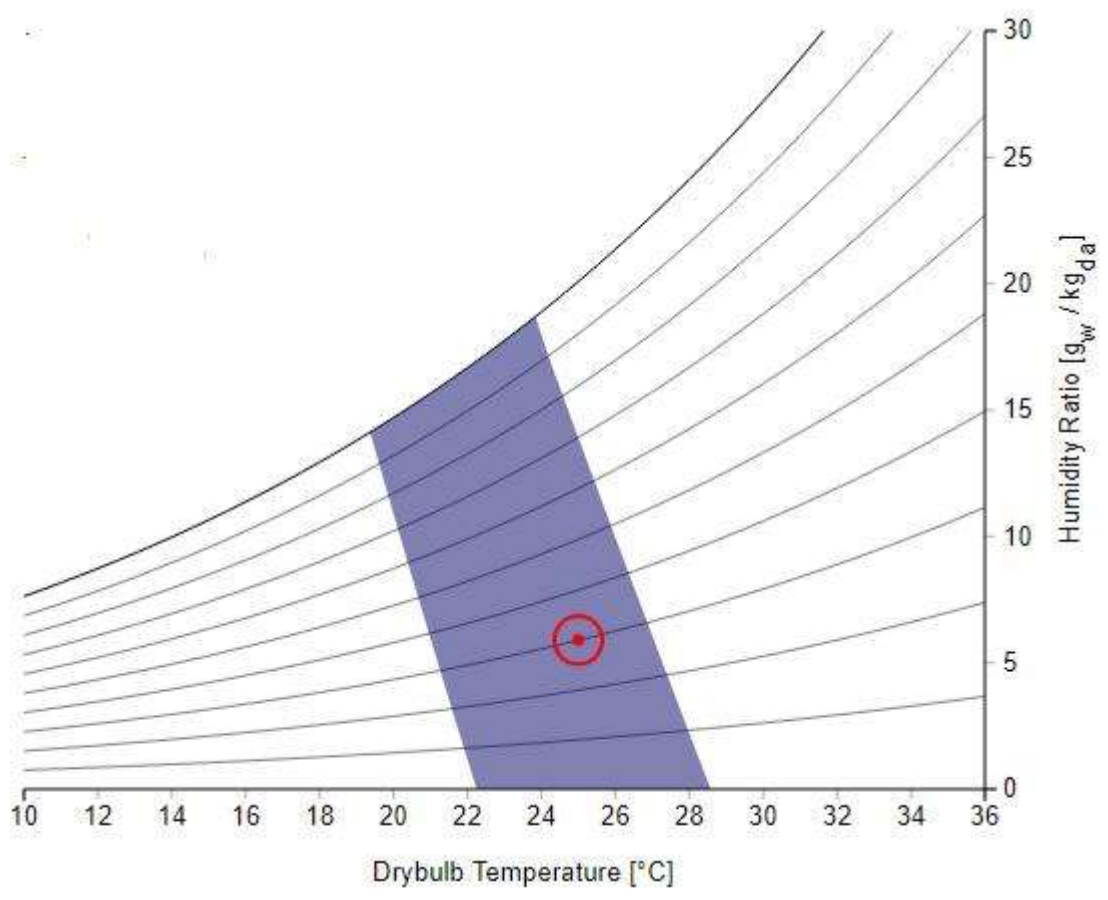

Figure 10: The Relation between Dry Bulb Temperature and Humidity Ratio 
Thermal comfort is achieved as shown in the following figure from temperature $22^{\circ} \mathrm{c}$ to $27^{\circ} \mathrm{c}$. The thermal comfort is achieved using the design-builder simulation tool. Energy saved from the thermal comfort and not using air-conditioning system is about $\left(7.5 \mathrm{~kW}^{*} 6 \mathrm{~h}=45 \mathrm{kwh} /\right.$ day) and monthly saved energy due to thermal comfort is about $1350 \mathrm{Kwh}$. Figure 11 , shows the relation between the window to wall ratio and temperature. The relation between Window to wall ratio and temperature of the room as shown in the following figure, if the WWR increased the temperature will increase and daylighting will increase. Minimum window to wall ratio is $20 \%$ and the maximum is $30 \%$.

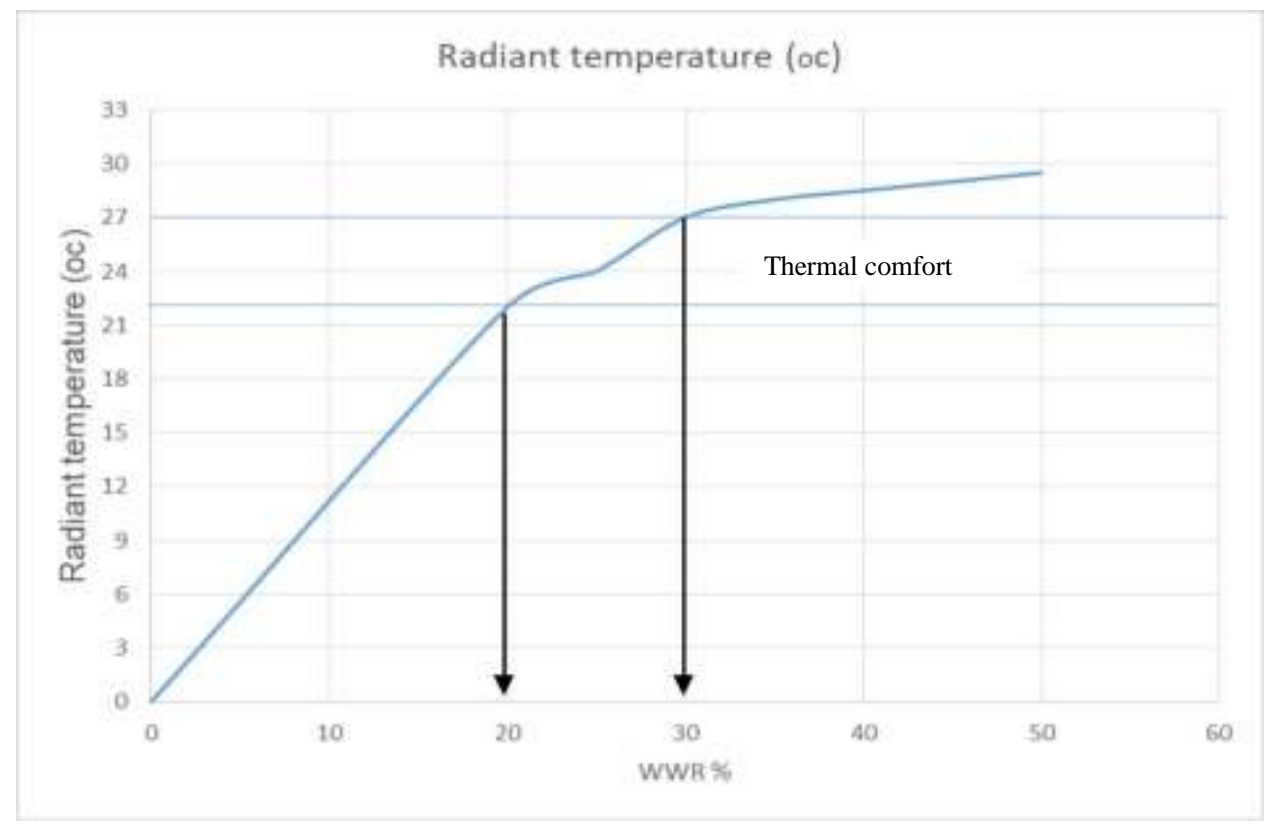

Figure 11: Relation between Window to Wall Ratio and Temperature

Figure 12, shows the relation between the temperature of the indoor room and time of year and comfort zone.

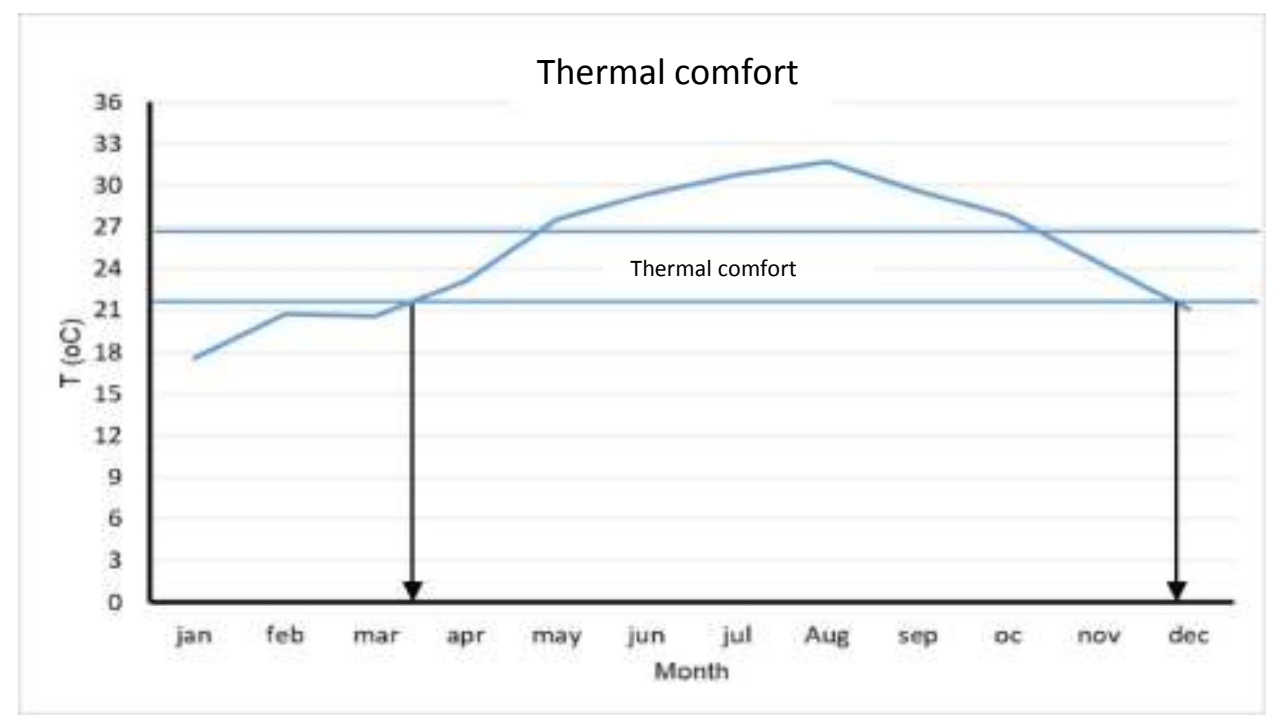

Figure 12: Relation between Temperature and Annual Time

\section{CONCLUSION}

In this paper, Daylighting is used as a tool for energy saving in buildings. A case study with a proposed building model in new elFarafra oasis is investigated. Results show that the importance of daylighting for any space in any building. In this paper, the energy saved from daylighting for the mentioned cases is presented in all seasons. The monthly energy saved for all proposed building by Daylighting is about $83.1 \mathrm{kWh}$, and that saved by thermal comfort is about $1350 \mathrm{kWh}$. Thermal comfort is achieved by using the PMV/PPD model where, PMV= 0.2 within acceptable limits and PPD $=6 \%$. 
M. Osama abed el-Raouf et. al., Day lighting as a tool of energy saving in buildings ....

\section{REFERENCES}

[1] https://www.lightourfuture.org/home/importance-of-light.

[2] C. Sapia, "Daylighting in buildings: Developments of sunlight addressing by optical fiber" solar energy, Vol.89, pp. 113-121, March 2013. https://doi.org/10.1016/j.solener.2012.12.003.

[3] Jozef Hraska, "Chronobiological aspects of green buildings Daylighting” Renewable Energy, Vol. 73 pp. 109-114, 2015.

[4] A. Tsangrassoulis, D.H.W. Li, "Energy efficient lighting strategies in buildings" Energy and Buildings Vol. 165, pp. 284-285, 15 April 2018.

[5] Rehab M. Ahmad, Rabee M. Reffat, "A comparative study of various Daylighting systems in office buildings for improving energy efficiency in Egypt” Journal of Building Engineering, Vol. 18, pp. 360-376, July 2018.

[6] Alrubaih MS, Zain MFM, Alghoul MA, Ibrahim NLN, Shameri MA, Elayeb O. Research and development on aspects of Daylighting fundamentals. Renewable and Sustainable Energy Reviews, pp. 494-505, 2013.

[7] McHugh J, Pande A, Ander G, Melnyk J. Effectiveness of photo controls with sky lighting. In: proceeding of the IESNA Annual Conference, Tampa, Florida, pp. 1-18, 25-28, July 2004.

[8] Abouelfadl S, El-Lithy KH Impact Assessment of Global warming on Egypt. Int J Engg Advtechnol3, pp. 352-360, 2014.

[9] Abouelfadl S, Ouda KH, Atia A, Al-Amir N “The Egyptian Gardens' City- A New City in the Western Desert (EGCWD) -A primary master plan". International Conference on Energy and Sustainability, NED University of Engineering and Technology, Pakistan, 2013.

[10] Abouelfadl S, Ouda K, Atia A, AL-AMIR N, Ali M, et al. "Radical Urban Development in the Egyptian Desert". J Fundam Renewable Energy Appl 5: 158. Do 10.4172/20904541.1000158, 2015.

[11] Luo, Maohui Wang, Zhe Ke, Kevin "Human metabolic rate and thermal comfort in buildings: The problem and challenge" Building and Environment, 13. March 2018.

[12] Krarti M, Erickson PM, Hillman TC. A simplified method to estimate energy savings of artificial lighting use from Daylighting. Building and Environment, pp. 747-754, 2005.

[13] ANSI/ASHRAE Standard 55-2013, Thermal Environmental Conditions for Human Occupancy.

[14] Xue P, Mak, CM, Cheung HD. The effects of Daylighting and human behavior on luminous comfort in residential buildings: A questionnaire survey. Building and Environment, pp. 51-59, 2014. 